\title{
Future Challenges in Higher Education - Bologna Experts' Community Case Study
}

\author{
Miri Yemini ${ }^{1}$ \\ ${ }^{1}$ School of Education, Tel Aviv University, Israel \\ Correspondence: Miri Yemini, The Jaime and Joan Constantiner School of Education, Tel Aviv University, Ramat \\ Aviv, Tel Aviv 69978, Israel. E-mail: miriye@post.tau.ac.il
}

\author{
Received: April 30, 2012 Accepted: May 22, 2012 Online Published: September 16, 2012 \\ doi:10.5539/ies.v5n5p226 URL: http://dx.doi.org/10.5539/ies.v5n5p226
}

\begin{abstract}
This work presents results from systematic analysis of the challenges for the future of higher education in European and neighboring countries as it was extracted from the Bologna experts and Higher Education Reform experts' opinions. Opinions of more than 100 experts from 35 countries were documented and analyzed. Significant differences in the opinions on future challenges in higher education were found to be addressed by opinions of experts from European Union in comparison to neighbouring countries. Differences were recorded in the amount and scope of challenges presented by experts from different countries and also the data collected differs significantly from the official policy for future development as reflects from official documentation of the European Commission. This work provides an insight into the bottom up implementation of the Bologna process and it can be useful for academics and policymakers in the field of higher education.
\end{abstract}

Keywords: higher education, bologna process, internationalization, challenges, universities

\section{Introduction}

The world of higher education and the world in which higher education plays a significant role are changing. Key drivers for change include the development of advanced communication and technological services, increased international labor mobility, greater emphasis on the market economy and trade liberalization, the focus on the knowledge society, increased private investment and decreased public support for education, and the growing importance of lifelong learning (Horta 2009, King 2010, Knight 2006). Higher education systems also become extremely influential in the various arenas outside education, including foreign policy and regional development arenas, and in cultural, social and economical spheres (Knight 2006).

In the last decades of the twentieth century, the theme of internationalization in higher education has gained increasing relevance and attention by scholars and policy makers around the globe (Dolby and Rahman 2008). Internationalization, as defined in 2004 by Jane Knight (Knight 2004), is the process of integrating an international, intercultural and/or global dimension into the purpose, functions (teaching, research and service) and delivery of higher education.

Among the most significant transitions in the field of higher education in the last decades, the geo-political reforms following the expansion of the European Union joint agenda enclosed to the Bologna process should be mentioned (Papatsiba 2006, Walkenhorst 2008). These reforms are now driving towards modernization and standardization of the higher education system in Europe and neighboring countries (Bing and Yuan 2003). Another process driven by these reforms is the 'academization' of the labor market causing employers to demand higher education diplomas for professions in which this wasn't required before (Akar 2010). Other significant transitions that have highly influenced higher education systems, include the wide availability of fast and mobile internet connections (Bahcecik and Alpar 2009, Ynalvez and Shrum 2009), and the development in distant learning and technology based learning. These transitions enable people from distant and poor regions to join education activities and even gain higher education degrees. The amount of students studying outside their homeland has risen from 800,000 in 1975 to more than 3.3 million students in 2010 and increasing numbers of academic staff work and live in international environments (OECD 2010). Together with this blessed diversity, 'brain drain' has become one of the most burning problems in small and less developed countries, and immigration laws in several regions were legislated to partly protect local communities (Stark and Fan 2010). Current global financial crises, alongside fierce competition between national higher education institutions, 
naturally led to cross-border expansion and international competition over the titles of 'World class' and 'Global' universities. Academic research has also become truly international with an increasing number of articles published as a result of international collaboration. The European research funding framework has largely facilitated this process, providing large scale funding for international projects and built-in multinational collaborations.

All the above mentioned challenges are substantial to the further development of the higher education systems and to leading the world in research, development and education. Stability and economic development are key factors directly influenced by the quality and accessibility of higher education. Permanent budget deficiency, place direct challenge to researchers and policy makers in that field for best resource allocation together will assessment and analysis of existing, past and future programs. This work is aimed to map the future pathways of higher education system in Europe and neighbouring countries and to compare the current state and scope of the experts' opinions in different countries and regions together with comparison to the European and national development policies. This paper will shed a light on the key points to be addressed by researchers and government officials in the field of higher education around the world.

\subsection{Bologna Process}

In many respects, the Bologna Process has been revolutionary for cooperation in European higher education (Witte, Wende, and Huisman, 2008). Four education ministers participating in the celebration of the $800^{\text {th }}$ anniversary of the University of Paris shared the view that the segmentation of the European higher education sector in Europe was outdated and harmful. The decision to engage in a voluntary process to create the European Higher Education Area (EHEA) was formalized one year later in Bologna, by 30 countries (Bologna Declaration 1999). It is now apparent that this was a significant undertaking as the process today includes no fewer than 47 participating countries, out of the 49 countries that have ratified the European Cultural Convention of the Council of Europe.

The Bologna process (Bologna Declaration 1999) is a long-term, geographically, economically and structurally extensive process. It has been adopted by the higher education systems in Europe and many neighbouring countries over the last decade. The essence of the process is an attempt to 'promote citizens' mobility and employability', and increase the international competitiveness of European higher education vis-à-vis the rest of the world (Witte, Wende, and Huisman, 2008). The process itself is more comprehensive than its mere academic components (Heinze and Knill 2008), namely, it is guided by the general concept of turning Europe and its neighbours into an entity of economic, social and political power, able to face the current and future super powers - the United States, China, Japan and India, in economics and global politics (Shin and Harman 2009). The cooperation needed to achieve such goals should consist of a common infrastructure, enabling the European continent and any countries associated with it to join the global game as a single entity. One essential aspect of such infrastructure is the establishment of a continental higher education system, which would lead to significant changes in all countries' education systems and subsequently in their professional training systems. This, in turn would extend the mobility of students, graduates and professionals in many fields, generating a cultural, social and economic structure with a broad and powerful denominator. At its inception, the Bologna Process was meant to strengthen the competitiveness and attractiveness of the European higher education and to foster student mobility and employability through the introduction of a system based on undergraduate and postgraduate studies with easily readable programs and degrees. Quality assurance has played an important role from the outset, too (Rauhvargers 2011). However, the various ministerial meetings since 1999 have broadened this agenda and have given greater precision to the tools that have been developed. The undergraduate/postgraduate degree structure has been modified into a three-cycle system, which now includes the concept of qualifications frameworks, with an emphasis on learning outcomes. Also, the concept of social dimension of higher education has been introduced and recognition of qualifications is now clearly perceived as central to the European higher education policies (Michavila, and Parejo 2008).

In March 2010, the Ministers responsible for higher education of 47 European countries that had signed the Bologna Declaration and committed to its reform agenda launched the European Higher Education Area (EHEA). The resulting Budapest-Vienna Declaration stressed that much had been achieved in implementing the ambitious reforms launched by the Bologna Declaration in 1999 but that further adjustments and work were necessary. In particular, that progress in implementation was not the same in all signatory countries, some action lines were implemented to varying degrees and others were not properly implemented and neighbouring countries also are entering the process to various degrees of understanding and adoption. In general, huge variations in the national education systems together with political tension between different countries inside the European Union and between them and the neighbouring countries and areas reveal great challenges over the implementation and adoption of the process and its implications. Several international communities were established to support and 
monitor this process and various financial tools were implied be the European Commission to promote the adoption procedures.

\subsection{Bologna and Higher Education Reform (HER) Experts}

Among community based activities around Bologna Process implementation, National Teams of the Bologna Experts play important role. The purpose of the National Teams of Bologna Experts is to provide a pool of expertise to promote and enhance progress toward higher education reform in their countries. The Activity Plan for the National Teams makes sure that all those involved in Higher Education on a national level benefit from the pan-European nature of these reforms. The National Teams of Bologna Experts comprise of senior academics and governmental officials in the field of higher education and function under the direction of national authorities for Higher Education, where applicable in cooperation with the national authorities for the Lifelong Learning Programme (LLP). The LLP National Agencies provide administrative and financial support, as well as support with regard to the content, to the National Teams of Bologna Experts, under the guidance of the national authorities. The overall objective of the bologna experts' community is to assist institutional implementation of reforms in higher education through materials, case studies, the virtual community-website and training seminars which provide a European dimension and a comparative perspective.

HER experts are officials and academics from neighbouring countries (outside EHEA), that had being appointed by the ministries of education or similar national authorities and are responsible for learning and possible adoption of Bologna process key elements in neighbouring countries. The countries that included under that definition comprise of: 4 countries of the Western Balkan region: Albania, Bosnia and Herzegovina, Montenegro, Serbia and Kosovo, 17 countries in the Southern and Eastern neighboring area of the European Union: Algeria, Egypt, Israel, Jordan, Lebanon, Libya, Morocco, the occupied Palestinian territory, Syria, Tunisia, Armenia, Azerbaijan, Belarus, Georgia, Moldova, the Russian Federation and Ukraine, and 5 central Asian Republics: Kazakhstan, Kyrgyzstan, Tajikistan, Turkmenistan and Uzbekistan.

Joint forum for Bologna and HER experts was established in 2005 to promote mutual understanding, and to facilitate cooperation and synergy between different stakeholders of the process. The financial tool to promote Bologna agenda that is available for partner countries is Trans-European Mobility Programme for University Studies (TEMPUS) programme. TEMPUS is the European Union's programme which supports the modernization of higher education in the Partner Countries of Eastern Europe, Central Asia, the Western Balkans and the Mediterranean region, mainly through university cooperation projects. The overall objective of the programme is to contribute towards facilitating cooperation in the field of higher education among Member States of the European Union (EU) and partner countries in the surrounding area. In particular, the programme assists to promote voluntary convergence with EU developments in the field of higher education, deriving from the Europe 2020 Strategy, the Strategic Framework for European Cooperation in Education and Training and the Bologna process.

This work is based on structural and systematic analysis of opinions expressed by Bologna and HER experts on the future challenges in internationalization of higher education with emphasis on new profiles of learners and different approaches to learning. First the methodology of the study will be detailed and then the results will be presented and discussed. Finally, the policy implications and practical measures will be suggested.

\section{Methodology and Results}

The aim of the current study was to gather and comprehensively examine the opinions of Bologna and HER experts on future challenges according to their perceptions for higher education systems in their home countries. Data collection was performed during the Modernization of Curricula seminar for Bologna and HER experts that was held in Oslo, between 6-7 June 2011.

More than 150 experts from more than 50 countries participated in that event, and experts were instructed ahead to sign in to 3 out of 5 elective workshops on various subjects related to Bologna process implementation and higher education in general. Each workshop was delivered 3 times, each time for 35-40 participants. The experts were randomly affiliated to one of the groups and each workshop lasted for approximately 2 hours. The workshops were delivered in interactive and shearing method, where at the beginning of the workshop the group was asked to extract and write down one main challenge for the future of higher education in their home country in the context of internationalization. All the answers were collected and the home country of each expert was also documented. The answers were used later for the sake of the workshop. After the workshops all answers were documented, screened and categorized. The categorization process had two main steps, where in the first step all the answers were screened by two independent readers and the keywords in each answer were highlighted (Oplatka 2006). In the second step, the answers were gathered into 10 different categories agreed by both readers. In the next step the 
answers were selected according to nationality affiliation and all answers were gathered together. The results presented in Table 1 for Bologna experts from countries of European Union and in Table 2 for neighbouring countries. Figure 1, graphically presents the combination of two tables.

Table 1. Bologna experts' opinions for future of higher education

\begin{tabular}{|c|c|c|c|c|c|c|c|c|c|c|c|c|c|c|c|c|c|c|c|c|c|c|c|c|c|c|c|}
\hline \multicolumn{28}{|l|}{ Challe nges/ } \\
\hline Countries & $\ddot{\square}$ & $\ddot{8}$ & \& & $\stackrel{\square}{\pi}$ & $\underset{\square}{\square}$ & \pm & $\bar{F}$ & 因 & 涪 & $\bar{z}$ & $\exists$ & 2 & ¿ & 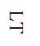 & $\Xi$ & $\Xi$ & $\preceq$ & $\sharp$ & 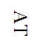 & $\stackrel{?}{?}$ & 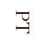 & $\pi$ & $\underline{n}$ & $\frac{n}{x}$ & $\exists$ & $\frac{5}{12}$ & $\stackrel{\check{\pi}}{\lambda}$ \\
\hline Fæu ulty & & $\mathrm{x}$ & $\mathrm{x}$ & $\mathrm{x}$ & & & $\mathrm{x}$ & $\mathrm{x}$ & $\mathrm{x}$ & & & & $\mathrm{x}$ & $\mathrm{x}$ & & $x$ & & & $\mathrm{x}$ & $\mathrm{x}$ & & $\mathrm{x}$ & $\mathrm{x}$ & & & $\mathrm{x}$ & $\mathrm{x}$ \\
\hline \multicolumn{28}{|l|}{ abilities } \\
\hline \multicolumn{28}{|l|}{ (student } \\
\hline \multicolumn{28}{|l|}{ centered } \\
\hline \multicolumn{28}{|l|}{ teaching) } \\
\hline E-learning & & & & & & & $\mathrm{x}$ & $\mathrm{x}$ & & & & & & & & & & & & & & & $\mathrm{x}$ & & & & \\
\hline \multicolumn{28}{|l|}{ and ICT } \\
\hline Quality/Incr & & & & & & & & & & & & & & & & $\mathrm{x}$ & & $\mathrm{x}$ & & & & & & & & & $\mathrm{X}$ \\
\hline \multicolumn{28}{|l|}{ easing } \\
\hline \multicolumn{28}{|l|}{ numbers of } \\
\hline \multicolumn{28}{|l|}{ students } \\
\hline Adult & $\mathrm{x}$ & $\mathrm{x}$ & $\mathrm{x}$ & & & $\mathrm{x}$ & $\mathrm{x}$ & $\mathrm{x}$ & & & & & $\mathrm{x}$ & & & & & & & $\mathrm{x}$ & & $\mathrm{x}$ & & & & & \\
\hline \multicolumn{28}{|l|}{ leamers and } \\
\hline \multicolumn{28}{|l|}{ LLL } \\
\hline Leamers' & & $\mathrm{x}$ & & & & $\mathrm{x}$ & & & & & & & & & & & $\mathrm{x}$ & $\mathrm{x}$ & & & & $\mathrm{x}$ & & & & & \\
\hline \multicolumn{28}{|l|}{ motivaion } \\
\hline Teachers' & & & & $\mathrm{x}$ & & & & & & & & & & & & & & & & & & & & & & & \\
\hline \multicolumn{28}{|l|}{ motivaion } \\
\hline Cunicula & $\mathrm{x}$ & $\mathrm{x}$ & & & & & & $\mathrm{x}$ & & $\mathrm{x}$ & $\mathrm{x}$ & & & & & & & $\mathrm{x}$ & & $\mathrm{x}$ & & & & & & $\mathrm{x}$ & \\
\hline \multicolumn{28}{|l|}{ for } \\
\hline \multicolumn{28}{|l|}{ workplace } \\
\hline Cultural & & & & & & & & & & $\mathrm{x}$ & & & $\mathrm{x}$ & & & & & & & & & & & & & $\mathrm{x}$ & \\
\hline \multicolumn{28}{|l|}{ differences } \\
\hline \multicolumn{28}{|l|}{ Increased } \\
\hline \multicolumn{28}{|l|}{ accessibibity } \\
\hline \multicolumn{28}{|l|}{ Increase } \\
\hline mobility & & & & & & & & & & & & & & & & & & & & & & & & & & & \\
\hline
\end{tabular}

Table 2. HER experts' opinions for future of higher education

\begin{tabular}{|c|c|c|c|c|c|c|c|c|c|c|c|c|c|c|}
\hline Challenges/Countries & $\mathrm{AZ}$ & $\mathrm{BA}$ & IL & $\mathrm{ME}$ & $\mathrm{RS}$ & RU & $\mathrm{TJ}$ & UA & $\mathrm{UZ}$ & Kosovo & Turkey & MD & $\mathrm{AM}$ & $\mathrm{KZ}$ \\
\hline $\begin{array}{l}\text { Faculty abilities } \\
\text { (student centered teaching) }\end{array}$ & & $\mathrm{X}$ & & $\mathrm{X}$ & $\mathrm{X}$ & $\mathrm{X}$ & $\mathrm{X}$ & & $\mathrm{X}$ & $\mathrm{X}$ & $\mathrm{X}$ & $\mathrm{X}$ & $\mathrm{X}$ & $\mathrm{X}$ \\
\hline E-learning and ICT & $\mathrm{X}$ & & $\mathrm{X}$ & & & & & & & & $\mathrm{X}$ & & & \\
\hline $\begin{array}{l}\text { Quality/Increasing numbers of } \\
\text { students }\end{array}$ & & & $\mathrm{X}$ & & & & & & & & & & & \\
\hline \multicolumn{15}{|l|}{ Adult learners and LLL } \\
\hline Learners' motivation & & & & $\mathrm{X}$ & & & & & & & & & & \\
\hline Teachers' motivation & & & & & $\mathrm{X}$ & & & & $\mathrm{X}$ & & & & & \\
\hline Curricula for workplace & & & $\mathrm{X}$ & & & & & & & & & & & \\
\hline \multicolumn{15}{|l|}{ Cultural differences } \\
\hline Increase accessibility & & & & & & & & & $\mathrm{X}$ & & & & & \\
\hline Increase mobility & & & & & & & & $\mathrm{X}$ & & & & & & \\
\hline
\end{tabular}




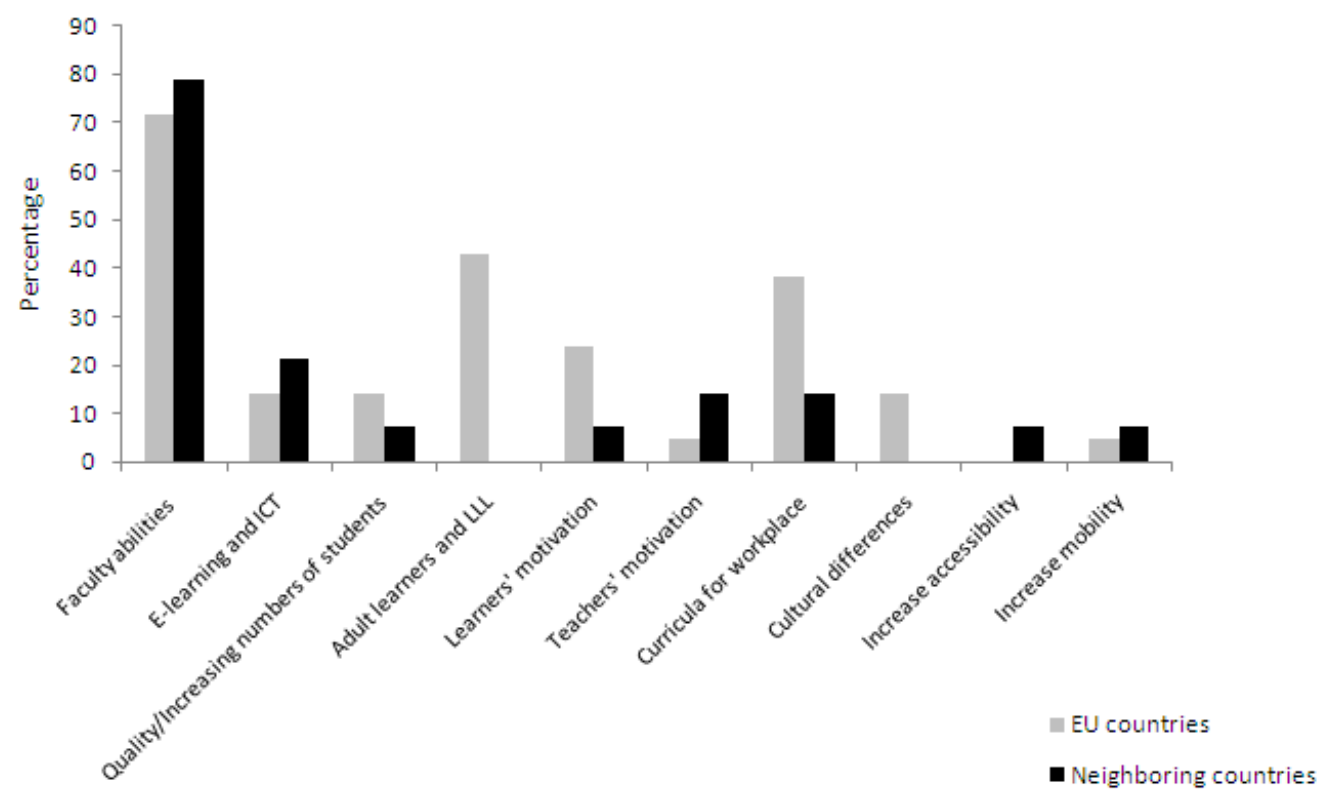

Figure 1. Bologna and HER experts opinions for future of higher education

\section{Discussion}

Tremendous challenges figurehead the higher education systems at the second decade of the $21^{\text {th }}$ century. Political and economical tension to enhance access for higher education create debate on quality standards and scalability, immigration and mobility from distant areas cause increasing conflicts over culture and tradition inside the system together with 'brain drain' and budget deficiency of the universities and colleges. Fast technological developments raise tough questions on intellectual property rights and technology accessibility on one hand with huge change in the profile of the new learners and new market professions on the other. Internationalization of higher education becomes a major player in the arenas of global competition over students, staff and resources together with severe budget cuts of public funding in all arenas.

The universities of today are dealing with fierce competition inside and outside their national field and even the very essence of higher education as a key for social mobility and prosperity is under a burning question at some audiences. This work was initiated to get an insight into the opinions of higher education experts on the future challenges of higher education in framework of internationalization and voluntary participation in implementation of Bologna process. At first, leading challenges as it was presented by the experts were collected and mapped. One of the first striking findings was that more than eighty percents with twenty seven out of thirty five countries mentioned student centered teaching and faculty abilities to comply with new profile of learners and new ways to learn as the most important future challenge in their national higher education systems. Interesting to note that student centered teaching was a universal challenge both in European Union countries and in neighbouring countries. It might be that addressing teachers' capabilities hides more general concerns on the quality and functionality of higher education in times of severe public financing that reflect on teaching quality like amount of students per lecturer, access to data and technology, e-learning and other parameters (Fernandez et.al. 2011). General concern over the quality of higher education was also major funding in informal discussions and interviews that were held during the seminar as well as from academic arena as presented in Shin and Harman (Shin and Harman 2009) and others.

The collected data reveals another unexpected phenomenon, with around fifty percents of the experts declared lifelong learning as a leading challenge in the future of higher education. Here, a significant difference was found between experts from European Union and experts from neighbouring countries, with almost exclusive interest in LLP from countries from European Union. Lifelong learning became one of the key aspects in sustainability of higher education in Europe and beyond it (Hallsten 2011). The frequent technological advancements, globalization and increased competition, send the employers to look for more skilled and updated workers, thus in turn chained for more top level academic education. Mobility and flexibility in learning, implies on the universities' obligation 
for fair accreditation and high availability during the workers' career. Lifelong learning not only provides a solution for rapidly changing workplace, but also enables the less privileged parts of the society to join the education wave including adult populations, immigrants and others. Visible absence of that challenge from opinions presented by HER experts from neighbouring countries implies on the development axis of higher education systems, where first reforms are directed towards young and relatively strong population in terms of widening access and only later, the policymakers and academics give attention to continuous learning and to older populations. The vertical development suggestion might be too rigid for the case of higher education, but it is clear that those nations who will choose to invest in the lifelong learning procedures from the very beginning will benefit from more balanced and equal society (Hallsten 2011).

The lifelong learning challenge deeply interconnected to another challenge that was mentioned by several experts and appeared only in answers collected from the European Union experts, the academia - industry cooperation. Thirty eight percent of Bologna experts mentioned this challenge as one of the leading future challenges for higher education. The academia-industry relations are a parameter of common public debate in terms of study programs, technology transfer, and the role of academic studies in the industry's needs and wants. It is widely accepted (Niedergassel and Leker 2011) that this link is important to all stakeholders involved and leading universities around the world invest significant resources to better understand the industry needs and to fulfil them as possible. Interesting to note, that this challenge hadn't been mentioned by experts from neighboring countries except from Israeli experts. This might be because higher education system in Israel is much closer to Europe than to neighbouring countries in terms of intellectual property, publications and quality assurance. Israel is also taking part in European research framework as one of the European countries and it might be needed to analyze its placement among neighbouring countries also under education framework.

Next, we considered more differences in the answers of experts from European Union and experts from neighbouring countries. Albeit similar delegations' size from all countries, Bologna experts had presented on average 2.05 challenges per country, comparing to 1.5 challenges that were presented by HER experts from neighbouring countries. Lower participation of experts from neighbouring countries might be in part explained by insufficient mastery in English language but also might reveal cultural and political differences between the two. No significant differences were found from European Union experts and between countries who recently joined the Union and those from Western Europe. Another phenomenon that should be presented is the accessibility goals in national systems, where Bologna experts direct their efforts into older and informal populations and learning settlements while HER experts focus on widening access for young students in their countries. Students and teachers motivation are playing a significant role for HER countries and cultural difference more discussed by Bologna experts.

Next, we were inspired to investigate the compliance of future challenges as articulated by Bologna and HER experts to official priorities for future projects in higher education system of neighbouring countries. TEMPUS support program, financed by European Commission to support the modernization of higher education and to foster creation of an area of co-operation in countries surrounding the European Union can be a valuable source of knowledge for the proposed EU policy. The European Commission through executive agency of education audiovisual and culture (EACEA) publish a yearly public call, with a list of national and regional priorities defined by the commission and the ministries of education in each of the neighbouring countries choose from the general list of priorities their national priorities and challenges. Table 3 presents an example from the 2010 call of global and national priorities as chosen by selected countries. Important to note that TEMPUS is a bottom up institutional cooperation program and academics can only submit proposals according to national and regional priorities, although the initial list of priorities is not originated from the countries but rather compelled by the European Commission. The general list of priorities includes: University management and student services, introduction of quality assurance, institutional and financial autonomy and accountability, equal and transparent access to higher education, development of international relations, training of non-university teachers, development of partnership with enterprises, knowledge triangle: education-research and innovation, training courses for public services, development of lifelong learning in society at large and qualification frameworks. The priorities are presented as governance reforms and higher education and society measures, but most of them presented in general and comprehensive way, usually include the Bologna Declaration agenda and comply with the official goals of Bologna process to promote a creation of common area of higher education (EHEA). 
Table 3. National priorities for Tempus projects funding (example from 2010 official call)

NATIONAL PRIORITIES FOR JOINT PROJECTS

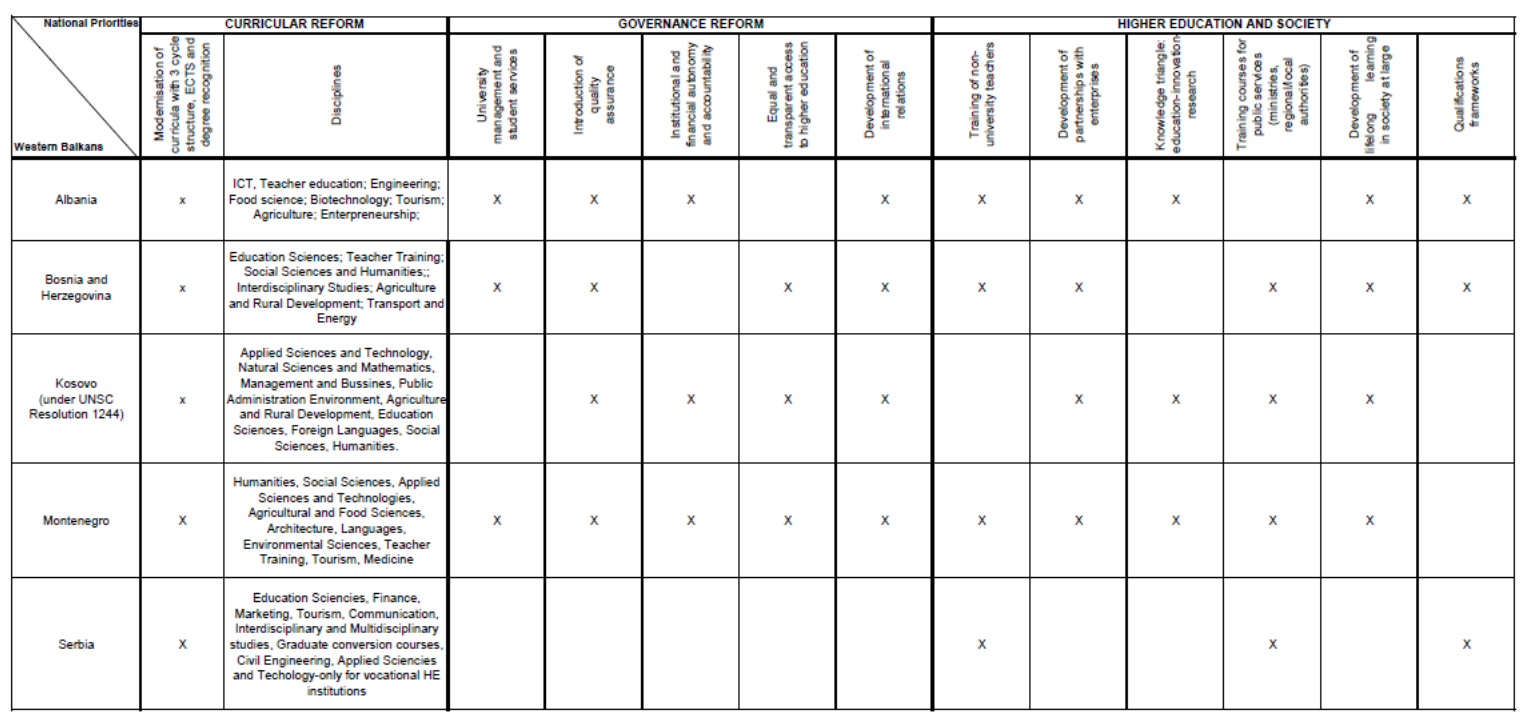

Table 4. National priorities for Tempus projects with HER experts' opinions for future of higher education

\begin{tabular}{|c|c|c|}
\hline National priorities (from EU official call) & $\begin{array}{l}\text { Future challenges of neighboring countries } \\
\text { as appears in experts' opinions }\end{array}$ & $\begin{array}{l}\mathrm{Nu} \text { of neighboring } \\
\text { countries' answers }\end{array}$ \\
\hline $\begin{array}{l}\text { University management and student } \\
\text { services }\end{array}$ & $\begin{array}{l}\text { Faculty abilities and student centered } \\
\text { teaching }\end{array}$ & 11 \\
\hline Introduction of quality assurance & Quality/Increasing numbers of students & 1 \\
\hline $\begin{array}{l}\text { Institutional and financial autonomy and } \\
\text { accountability }\end{array}$ & & 0 \\
\hline $\begin{array}{l}\text { Equal and transparent access to higher } \\
\text { education }\end{array}$ & Increase accessibility & 1 \\
\hline Development of international relations & & 0 \\
\hline Training of non-university teachers & & 0 \\
\hline $\begin{array}{l}\text { Development of partnership with } \\
\text { enterprises }\end{array}$ & Curricula for workplace & 1 \\
\hline $\begin{array}{l}\text { Knowledge triangle: education-research } \\
\text { and innovation }\end{array}$ & & 0 \\
\hline Training courses for public services & & 0 \\
\hline $\begin{array}{l}\text { Development of lifelong learning in } \\
\text { society at large }\end{array}$ & & 0 \\
\hline \multirow[t]{5}{*}{ Qualification frameworks } & & 0 \\
\hline & E-learning and ICT & 3 \\
\hline & Learners' motivation & 1 \\
\hline & Teachers' motivation & 2 \\
\hline & Increase mobility & 1 \\
\hline
\end{tabular}

Important to stress the fact that the mentioned priorities are aimed only to higher education systems in neighbours' countries and not to European Union members. Comparison of challenges raised by Bologna and HER experts to priorities depicted by European Commission show that there are several areas of high concern to HER experts but those are not mentioned in the official call, especially in field of motivation and specific measures. Table 4 summarizes the priorities of the official call in front of experts' answers and some alignment has been made to allow fair comparison. A glance at the table shows us the differences between the experts' opinions and the official priorities as defined by the European Union. Although most of the neighbouring countries experts presented faculty capabilities and student centered teaching as a key challenge for the future, the scattering of the answers is 
surprising. Going back again to the proposed evolution of the higher education systems' development, it might be that the present challenges of the EU countries are actually the future challenges of the nigh neighbouring countries without direct relation to Bologna process but rather to democratization and globalization of higher education system in national context.

\section{Conclusions}

To summarize, this work presents gathering, mapping and analysis of Bologna and HER experts' opinions on future challenges and priorities for development of higher education systems in European and neighbouring countries. The challenges that were mapped are complex and diverse and some of them are not transparent enough to policymakers and academics. It is clear that significant differences exist between the opinions of experts from European countries and those from neighboring countries although differences weren't found among recent joining countries and Western Europe countries inside European Union. Interesting to note, that some core areas weren't covered at all by participating experts, although those have been abundant in the academic, political and economic debates in the field of higher education. Research and its derivatives as the inter-connection of research and teaching were discussed at all although academic debate over those issues is flourishing. The experts also haven't mentioned the broader aspects of internationalization as appears from official Bologna process publications. Education for special populations and impaired populations also weren't covered maybe due to lower percentage of those potential students in general population. The opinions of more than 100 experts from 35 countries enable an interesting glance over higher education systems in various environments. This work may contribute to the body of knowledge in higher education policies and might be useful for academics, students and policymakers in the area of higher education.

\section{References}

Akar, H. (2010). Globalization and its challenges for developing countries: The case of turkish higher education. Asia Pacific Education Review, 11(3), 447-457. http://dx.doi.org/10.1007/s12564-010-9086-0

Bahcecik, N., \& Alpar, S. E. (2009). Nursing education in turkey: From past to present. Nurse Education Today, 29(7), 698-703. http://dx.doi.org/10.1016/j.nedt.2009.05.008

Bing, L., \& Yuan, J. H. (2003). The effects of china's membership in wto on the internationalization of china's higher education and the countermeasures. Chinese Education and Society, 36(5), 69-79. http://dx.doi.org/10.2753/CED1061-1932360569

Bologna Declaration. (1999). The European higher education area: Joint declaration of the European Ministers of Education, convened in Bologna on the 19th of June 1999.

Dolby, N., \& Rahman, A. (2008). Research in international education. Review of Educational Research, 78(3), 676-726. http://dx.doi.org/10.3102/0034654308320291

Fernandez, C., Diez, D., Zarraonandia, T., \& Torres, J. (2011). A student-centered introductory programming course: The cost of applying bologna principles to computer engineering education. International Journal of Engineering Education, 27(1), 14-23.

Hallsten, M. (2011). Late entry in swedish tertiary education: Can the opportunity of lifelong learning promote equality over the life course? British Journal of Industrial Relations, 49(3), 537-559. http://dx.doi.org/10.1111/j.1467-8543.2010.00784.x

Heinze, T., \& Knill, C. (2008). Analysing the different impact of the bp: Theoreical considerations on national conditions for international policy convergence. Higher Education, 56(4), 493-510. http://dx.doi.org/10.1007/s10734-007-9107-z

Horta, H. (2009). Holding a post-doctoral position before becoming a faculty member: Does it bring benefits for the scholarly enterprise? Higher Education, 58(5), 689-721. http://dx.doi.org/10.1007/s10734-009-9221-1

King, R. (2010). Policy internationalization, national variety and governance: Global models and network power in higher education states. Higher Education, 60(6), 583-594. http://dx.doi.org/10.1007/s10734-010-9317-7

Knight (2004). Internationalization remodeled: Definition, approaches, and rationales. Journal of Studies in International Education, 8(1), 5-31.

Knight, J. (2006). Cross-border education: Conceptual confusion and data deficits. Perspectives in Education, 24(4), 15-27.

Knight, J. (2011) Education hubs: A fad, a brand, an innovation? Journal of Studies in International Education, 15(3), 221-240. http://dx.doi.org/10.1177/1028315311398046 
Michavila, F., \& Parejo, J. L. (2008). Student participation policies in the bologna process. Revista De Educacion, 85-118.

Niedergassel, B., \& Leker, J. (2011). Different dimensions of knowledge in cooperative r\&d projects of university scientists. Technovation, 31(4), 142-150. http://dx.doi.org/10.1016/j.technovation.2010.10.005

OECD. (2010). Education at a Glance OECD Indicators.

Oplatka, I. (2006). Women in educational administration within developing countries: Towards a new international research agenda. Journal of Educational Administration, 44(6), 604-624. http://dx.doi.org/10.1108/09578230610704819

Papatsiba, V. (2006). Making higher education more european through student mobility? Revisiting eu initiatives in the context of the bologna process. Comparative Education, 42(1), 93-111. http://dx.doi.org/10.1080/03050060500515785

Rauhvargers, A. (2011). Achieving bologna goals: Where does europe stand ahead of 2010. Journal of Studies in International Education, 15(1), 4-24. http://dx.doi.org/10.1177/1028315310373834

Shin, J. C., \& Harman, G. (2009). New challenges for higher education: Global and asia-pacific perspectives. Asia Pacific Education Review, 10(1), 1-13. http://dx.doi.org/10.1007/s12564-009-9011-6

Stark, O., \& Fan, C. S. (2010). The prospect of migration, sticky wages, and "educated unemployment". Review of International Economics, 19(2), 277-287. http://dx.doi.org/10.1111/j.1467-9396.2011.00946.x

Walkenhorst, H. (2008). Explaining change in eu education policy. Journal of European Public Policy, 15(4), 567-587. http://dx.doi.org/10.1080/13501760801996741

Witte, J., Van Der Wende, M., \& Huisman, J. (2008). Blurring boundaries: How the bologna process changes the relationship between university and non-university higher education in germany, the netherlands and france. Studies in Higher Education, 33(3), 217-231. http://dx.doi.org/10.1080/03075070802049129

Ynalvez, M. A., \& Shrum, W. M. (2009). International graduate science training and scientific collaboration. International Sociology, 24(6), 870-901. http://dx.doi.org/10.1177/0268580909343501 